\title{
Creators of competitiveness in the textile and clothing industry from the Hidalgo state
}

DOI: 10.35530/IT.071.03.1705

\section{ABSTRACT - REZUMAT}

\section{Creators of competitiveness in the textile and clothing industry from the Hidalgo state}

Nowadays, technological innovation is a very important agent not only in the business sector, but also in the research sector, especially when it is related to factors such as competitiveness, since it is perceived as a determinant for the future of the industry and business development. This research presents the development of the work "Generalities of the textile industry and its relevance in the business competitiveness of medium-sized companies in the state of Hidalgo" in which the competitiveness of some Hidalgo organizations in the industrial sector is analysed based on innovation in technology. The work consists of a theoretical review and the application of instruments to medium-sized companies in the industrial sector, considering the database of the Mexican Business Information System (SIEM). Based on the above, an instrument was created that allows knowing if the competitiveness in the industries depends on the technology implemented in these organizations. The work was carried out in two stages: in principle, a brief theoretical framework is developed in which the importance of innovation in technology for the competitiveness of companies in the textile industry is explained and, subsequently, the way is opened to the Field research, where this relationship is analysed for the particular case of medium-sized Hidalgo companies. It should be noted that these are the partial results derived from the creation of the measurement instrument and the application of a pilot test to these companies.

Keywords: technology, innovation, company, industrial sector, production

\section{Creatorii de competitivitate în industria textilă și de îmbrăcăminte din statul Hidalgo}

În zilele noastre, inovarea tehnologică este un agent foarte important nu numai în sectorul de afaceri, ci și în domeniul cercetării, mai ales atunci când este legată de factori precum competitivitatea, deoarece este percepută ca un factor determinant pentru viitorul industriei și al dezvoltării afacerilor. Această lucrare prezintă rezultatele cercetării „Generalități ale industriei textile și relevanța acesteia în competitivitatea în afaceri a companiilor mijlocii din statul Hidalgo", în care este analizată competitivitatea unor organizații din Hidalgo, în sectorul industrial pe baza inovării tehnologice. Lucrarea constă într-o documentare teoretică și aplicarea instrumentelor în companii mijlocii din sectorul industrial, utilizând baza de date a Sistemului de informații despre afacerile din Mexic (SIEM). Pe baza celor de mai sus, a fost creat un instrument care permite evaluarea competitivității din industrii în funcție de tehnologia implementată în aceste organizații. Lucrarea a fost realizată în două etape: inițial, este elaborat un cadru teoretic în care este explicată importanța inovării tehnologice pentru competitivitatea companiilor din industria textilă și, ulterior, se deschide calea către cercetarea pe teren, unde această relație este analizată pentru cazul particular al companiilor mijlocii din Hidalgo. Se menționează că acestea sunt rezultatele parțiale care provin din crearea instrumentului de măsurare și din aplicarea unui test pilot pentru aceste companii.

Cuvinte-cheie: tehnologie, inovare, companie, sector industrial, producție

\section{INTRODUCTION}

The present investigation belongs to the activities developed by the academic body Management and Business Development of the Institute of EconomicAdministrative Sciences (ICEA) of the Autonomous University of the State of Hidalgo (UAEH), and whose objective was to analyse the impact of technological innovation in medium-sized companies in the industrial sector within the State of Hidalgo.

The theoretical evidence highlights the need to know the factors that affect the achievement of high levels of competitiveness by organizations, factors that seem to be oriented towards innovation and optimal application of technologies in production processes [1].

\section{GENERAL INFORMATION}

The textile industry constitutes a significant sector for the economy of many countries due to its participation in the GDP and the generation of jobs [2]. In the case of Mexico, with the implementation of the North American Free Trade Agreement (NAFTA) it represented attraction of foreign investment, development of strategic alliances and access to technology, which, finally, would result in growth of the economy. However, there have been several phenomena that have negatively affected the dynamics of trade between the United States and Mexico [3].

The socioeconomic contribution of this sector was reflected in the creation of jobs, since the number of workers in the textile sector went from 42,231 in 1990 


\begin{tabular}{|l|c|c|c|c|c|c|}
\hline \multicolumn{7}{|c|}{ ELEMENTS OF THE PILOT TEST COMPANIES (N = 10) } \\
\hline Levels & Age & $\begin{array}{c}\text { Percentage of } \\
\text { foreign capital } \\
(\%)\end{array}$ & $\begin{array}{c}\text { Export } \\
\text { percentage } \\
(\%)\end{array}$ & $\begin{array}{c}\text { Number of } \\
\text { workers }\end{array}$ & Sales (\$) & $\begin{array}{c}\text { Number of patents, } \\
\text { prototypes and } \\
\text { copyrights }\end{array}$ \\
\hline Median & 18 & 5.9 & 6.3 & 275 & $77,757,140.50$ & 12 \\
\hline Total pilot test & 18 & 5.9 & 6.3 & 275 & $77,757,140.50$ & 12 \\
\hline
\end{tabular}

\section{Table 2}

\begin{tabular}{|l|c|c|c|c|c|c|c|c|}
\hline \multicolumn{7}{|c|}{ ELEMENTS OF THE COMPANIES INTERVIEWED (N = 10) } \\
\hline \multirow{2}{*}{$\begin{array}{l}\text { Dimension of } \\
\text { the company }\end{array}$} & Turn: sector 313 & \multicolumn{2}{c|}{ Turn: sector 314 } & \multicolumn{2}{|c|}{ Turn: sector 315 } & \multicolumn{2}{c|}{ Turn: sector 316 } \\
\cline { 2 - 9 } & Number & $\begin{array}{c}\text { Percentage } \\
(\%)\end{array}$ & Number & $\begin{array}{c}\text { Percentage } \\
(\%)\end{array}$ & Number & $\begin{array}{c}\text { Percentage } \\
(\%)\end{array}$ & Number & $\begin{array}{c}\text { Percentage } \\
(\%)\end{array}$ \\
\hline Median & 3 & 30 & 3 & 30 & 2 & 20 & 2 & 20 \\
\hline Total pilot test & 3 & 100 & 3 & 100 & 2 & 100 & 2 & 100 \\
\hline
\end{tabular}

to 26,559 ten years later [4]. However, this trend weakened as globalization favoured the pressure to increase competitiveness in terms of quality, productivity and flexibility from the shift of production activities to countries with the capacity to offer costs low labour costs [3].

On the other hand, in Mexico, the contribution of the textile and clothing sector to international trade reached the export leadership in the period between 1990 and 2002 when achieving a participation in the imports of EE. UU of $11.58 \%$, but the lack of technological innovation caused the loss of competitiveness against Asian and Eastern European countries at the beginning of the first decade of the $21^{\text {st }}$ century, mainly because labour costs no longer represent a competitive advantage, because those from countries such as China and India are even lower [4].

From an organizational approach, technology is conceived as the use of knowledge for the creation of goods and services, which make it one of the main mechanisms available to design, create and distribute their products [5].

The term technology is used to refer to the process by means of which tools are developed that elevate the control and understanding of the material context, this construct is made up of two kinds of knowledge: the codified and the tacit. Additionally, technologies are affecting the economic environment and, along with them, the needs of consumers, which are increasingly difficult to satisfy, which implies a challenge for companies to implement new strategies that allow them to be more competitive. Contemporary fashion trends and modern technologies impose more requirements to the textile industry.

The innovation is one of the most important factors for the so called "Knowledge Society", in which knowledge constitutes, precisely, a strategic element for all nations and organizations, where the correct management of it, represents improvements in com- petitiveness and survival within a globalized economy [6].

In the degree to which knowledge is oriented towards producing innovations, in that degree a greater development in technology will be achieved. The Economic Commission for Latin America and the Caribbean (ECLAC) highlights that among the main factors that distinguish the current economy are the following [7]:

- mostly codified knowledge;

- science and technology in close relationship, high innovation rates and a short product life cycle;

- greater relevance in continuous learning, in education and in the issue of innovation in GDP growth;

- lower investment in fixed capital and more in intangible factors (R\&D, education, software);

- labour market and its variability in demand.

Tables 1 and 2 show the results obtained from the application of the pilot test to the 10 medium-sized companies in the textile and clothing sector.

Table 3 shows the percentage of variance $\left(R^{2}=0.37\right.$, $p<0.01$ ) finding a statistically significant relationship between the variables "characteristics of companies in exports" $(\beta=0.42 ; p<0.01)$ and "infrastructure" (specifically in the dimension "renewal and expansion of products and services"). According to these results, renewal and expansion of the range of products is generated based on the presence of an export performance of medium-sized companies, so that medium-sized companies in the state of Hidalgo are competitive in their exports require the best infrastructure in their productive processes.

For its part, the results presented in table 4 show that there is a statistically significant relationship between the number of patents and utility models of companies and the variable "human capital formation", which indicates that innovation for the development of patents, utility models or copyright of companies $(\beta=-0.50 ; p<0.01)$ resides, to a large extent, in the 


\begin{tabular}{|c|c|c|c|c|}
\hline \multicolumn{5}{|c|}{$\begin{array}{l}\text { RESULTS OF THE HIERARCHICAL REGRESSION ANALYSIS OF THE PILOT TEST } \\
\text { (INFRASTRUCTURE/RENEWAL AND INCREASE OF THE VARIABILITY OF PRODUCTS AND SERVICES) }\end{array}$} \\
\hline Variable: Elements of the company & Step 1 & Step 2 & Step 3 & Step 4 \\
\hline Age & -0.05 & 0.08 & 0.05 & 0.05 \\
\hline Percentage of foreign capital & 0.05 & -0.07 & -0.07 & -0.09 \\
\hline Export percentage & - & $0.53^{* *}$ & $0.40^{* *}$ & $0.42^{* *}$ \\
\hline Sales & - & - & -0.03 & -0.02 \\
\hline Number of patents, prototypes and copyrights & - & - & - & 0.14 \\
\hline $\mathrm{R}$ & 0.09 & $0.30^{* *}$ & $0.30^{* *}$ & $0.32^{* *}$ \\
\hline $\mathrm{R}^{2}$ & 0.01 & $0.25^{* *}$ & $0.25^{* *}$ & $0.37^{* *}$ \\
\hline $\mathrm{R}^{2}$ Adjusted & 0.03 & 0.21 & 0.19 & 0.20 \\
\hline
\end{tabular}

Note: ${ }^{*} p<0.05$ and ${ }^{* *} p<0.01$

RESULTS OF THE HIERARCHICAL REGRESSION ANALYSIS OF THE PILOT TEST (FORMATION OF HUMAN CAPITAL)

\begin{tabular}{|l|c|c|c|c|}
\hline \multicolumn{1}{|c|}{ Variable: Elements of the company } & Step 1 & Step 2 & Step 3 & Step 4 \\
\hline Age & -0.06 & 0.08 & 0.05 & 0.05 \\
\hline Percentage of foreign capital & 0.06 & -0.07 & -0.07 & -0.09 \\
\hline Export percentage & -0.01 & -0.01 & 0.01 & -0.01 \\
\hline Sales & -0.01 & - & -0.01 & -0.02 \\
\hline Number of patents, prototypes and copyrights & $0.49^{* *}$ & $0.50^{* *}$ & $0.50^{* *}$ & $0.50^{* *}$ \\
\hline$R$ & 0.20 & $0.25^{* *}$ & $0.55^{\star *}$ & $0.52^{* *}$ \\
\hline$R^{2}$ & 0.01 & $0.35^{* *}$ & $0.35^{* *}$ & $0.38^{* *}$ \\
\hline$R^{2}$ Adjusted & 0.03 & 0.22 & 0.29 & 0.23 \\
\hline
\end{tabular}

Note: ${ }^{*} p<0.05$ and ${ }^{* *} p<0.01$

formation of their human capital, obtaining a percentage of explained variance of $R^{2}=0.38(p<0.01)$

In general terms, both analyses carried out in the pilot show a significant association between the variables innovation in infrastructure and training of human capital and exports and innovations of companies, but not with the age of the company and its sales volume.

\section{CONCLUSIONS}

Technological innovation is a very important factor in the achievement of business competitiveness, which also has an impact on the economic development of any country, since it is a guiding axis in the production of goods and services.

The partial results of this research show interesting aspects to be analysed: in the first instance, the positive relationship between the characteristics of the companies and the infrastructure and innovation in the production processes of these. Similarly the role of investment in intellectual capital and in the generation of knowledge that brings innovation from the creation of brands and patents, key factors in achieving competitiveness.

The objective of this study is to identify the influence of innovation in technology on the competitiveness of medium-sized companies in the textile and clothing sector in the state of Hidalgo, in turn, develop improvement proposals that allow them to be competitive in the regional market, National and international.

\section{ACKNOLEDGEMENTS}

The authors wish to express their gratitude to the companies that collaborated in the study, to the Autonomous University of the State of Hidalgo and to the Institute of Economic and Administrative Sciences, for allowing and supporting research.

\section{REFERENCES}

[1] Giacometti, L., Innovación tecnológica y desarrollo de ventaja competitiva en la atención a la salud: enfoque conceptual y metodológico, In: Revista Gerencia y Políticas de Salud, 2013, 12, 25, 66-82

[2] Ibercondor, La industria textil en México, Available at: https://ibercondor.com/blog/la-industria-textil-mexico/ [Accessed March 28th 2018] 
[3] Saucedo, O., La industria textil en México: TLCAN, China y la globalización. Un análisis a favor de una estrategia de desarrollo integral, Cátedra Levi Strauss-Anáhuac por la libertad de asociación en la industria de la confección, Centro Idearse, Universidad Anáhuac, 2013

[4] Arroyo, M., Cárcamo, M., La evolución histórica e importancia económica del sector textil y del vestido en México, In: Economía y sociedad, 2010, 14, 25, 51-68

[5] Londoño, J., Tecnología como factor de innovación en empresas colombianas, In: Revista venezolana de gerencia, 2015, 20, 70, 201-216

[6] Aponte, G., Gestión de la innovación tecnológica mediante el análisis de la información de patentes, In: Negotium, 2016, 11, 33, 42-68

[7] Ríos, H., Marroquín, J., Innovación tecnológica como mecanismo para impulsar el crecimiento económico, In: Evidencia regional para México. Contaduría y Administración, 2013, 58, 3, 11-37

\section{Authors:}

\section{TIRSO JAVIER HERNÁNDEZ-GRACIA, DANAE DUANA-AVILA}

Autonomous University of the State of Hidalgo, Institute of Economic and Administrative Sciences, Academic Area of Administration, La Concepción circuit, km 2.5, San Juan Tilcuautla Municipality of San Agustín

Tlaxiaca, Hidalgo, 42161, Pachuca Hidalgo, México

e-mail: thernan@uaeh.edu.mx

Corresponding author:

DANAE DUANA-AVILA

e-mail: danae@uaeh.edu.mx 